\begin{tabular}{cc|c}
\hline Tar. Bil. Der. & Journal of Agricultural Sciences \\
& $\begin{array}{c}\text { Dergi web sayfası: } \\
\text { www.agri.ankara.edu.tr/dergi }\end{array}$ & Journal homepage: \\
& www.agri.ankara.edu.tr/journal
\end{tabular}

\title{
Performance Analysis of a Greenhouse Fan-Pad Cooling System: Gradients of Horizontal Temperature and Relative Humidity
}

\author{
Mehmet Ali DAYIOĞLU ${ }^{a}$, Hasan Hüseyin SİLLELİ \\ a Ankara University, Faculty of Agriculture, Department of Agricultural Machinery, 06130, Ankara, TURKEY
}

\section{ARTICLE INFO}

Research Article

DOI: 10.1501/Tarimbil_0000001314

Corresponding Author: Mehmet Ali DAYIOĞLU, E-mail: dayioglu@agri.ankara.edu.tr, Tel: +90 (312) 59615

96 Received: 27 July 2014, Received in Revised Form: 01 October 2014, Accepted: 10 October 2014

\begin{abstract}
An experimental study is conducted to determine the performance parameters of system, as well as gradients of temperature and humidity along greenhouse when opening Fan-Pad cooling system. Measurements in the study were carried out by using seven sensors for different locations, as well as portable instruments. For this purpose, the five digital temperature and humidity sensors and two pyranometers were used during experiments. Among them, two were located outside greenhouse for external measurements. The rest one pyranometer above the crop canopy, four temperature and humidity sensors were mounted within the crop canopy along the greenhouse. Four sensors were placed according to positions defined between pad and fan. According to the experiment results, the non-uniform temperature changes, but approximately uniform humidity changes due to the crop transpiration were observed along greenhouse from pad panels to exhaust fans. When the cooling system closed, hourly mean temperature and relative humidity from Pad to Fan inside greenhouse changed between $30-33{ }^{\circ} \mathrm{C}$ and $30-47 \%$, respectively, at outside climate conditions of $32{ }^{\circ} \mathrm{C}$ and $25 \%$. After providing stabile cooling by opening Fan-Pad system, hourly mean temperature and relative humidity along greenhouse from pad to fan ranged between $20-27^{\circ} \mathrm{C}$, and $50-68 \%$, respectively. The air temperature entering to greenhouse with air velocity of $0.8-0.9 \mathrm{~ms}^{-1}$ through pad was approximately $12-13{ }^{\circ} \mathrm{C}$ lower than the outside air temperature. The air temperature from Pad to Fan increased approximately by $7{ }^{\circ} \mathrm{C}$. The method of psychrometric calculations was employed to determine the cooling efficiency of Fan-Pad system. According to the calculation result, the average of air temperatures inside greenhouse was $24.5^{\circ} \mathrm{C}$ after achieving stable cooling for outside air temperature of $31.4^{\circ} \mathrm{C}$. The hourly mean cooling effect and cooling efficiency calculated for Fan-Pad system were determined to be $6.96^{\circ} \mathrm{C}$ and $76.8 \%$, respectively.
\end{abstract}

Keywords: Cooling efficiency; Fan-Pad cooling system; Greenhouse; Psychrometric calculation; Temperature and relative humidity

\section{Sera Fan-Pad Soğutma Sisteminin Performans Analizi: Yatay Sıcaklık ve Bağıl Nem Değişimleri}

\section{ESER BILGISİ}

Araştırma Makalesi

Sorumlu Yazar: Mehmet Ali DAYIOĞLU, E-posta: dayioglu@agri.ankara.edu.tr, Tel: +90 (312) 5961596

Geliş Tarihi: 27 Temmuz 2014, Düzeltmelerin Gelişi: 01 Ekim 2014, Kabul:10 Ekim 2014 


\section{ÖZET}

Fan-Pad soğutma sistemi çalışırken sera boyunca oluşan sıcaklık ve bağıl nem değişimleri ve soğutma sistemi performans parametrelerini saptamak için deneysel bir çalışma yapılmıştır. Çalışmada ölçümler yedi farklı noktaya yerleştirilen sensörler ve taşınabilir ölçüm cihazları kullanılarak gerçekleştirilmiştir. Bu amaçla, beş dijital sıcaklık-nem sensörü ve iki güneş ışınım sensörü kullanılmıştır. Sensörlerden ikisi sera dışına, bir güneş 1şınım sensörü bitki örtüsü üstüne, dört sıcaklık-nem sensörü sera boyunca bitki örtüsü içine yerleştirilmiştir. Dört sensörün yerleşimi Pad ve Fan arasında tanımlanmış konumlara göre yapılmıştır. Elde edilen deney sonuçlarına göre, Pad tarafından fan tarafına sera boyunca homojen olmayan sıcaklık değişimleri, ancak transpirasyon nedeniyle yaklaşık homojen kalan bağıl nem değişimleri gözlemlenmiştir. Soğutma sistemi kapalı olduğu zaman, havanın $32{ }^{\circ} \mathrm{C}$ ve $\% 25$ olduğu koşullarda, sera içinde Pad tarafından fan tarafına saatlik ortalama sıcaklık ve bağıl nem değerleri sirasıyla $30-33{ }^{\circ} \mathrm{C}$ ve \% $30-\% 47$ arasında değişmiştir. Fan-Pad sistemi çalıştırılıp kararlı soğutma sağlandıktan sonra, sera boyunca saatlik ortalama sıcaklık ve bağıl nem değerleri sırasıyla $20-27^{\circ} \mathrm{C}$ ve \% $50-\%$ 68, arasında değişmiştir. Islak Pad yüzeyini geçerek yaklaşık $0.8-0.9 \mathrm{~m} \mathrm{~s}^{-1}$ hava hızla seraya giren hava sıcaklığı dış hava sıcaklığından $12-13^{\circ} \mathrm{C}$ daha düşük olmuştur. Pad tarafından fan tarafına sera boyunca hava sıcaklığı yaklaşı $7^{\circ} \mathrm{C}$ yükselmiştir. Buharlaşmalı Fan-Pad sisteminin soğutma etkinliğini hesaplamak için psikrometrik hesaplama yöntemi kullanılmıştır. Hesaplama sonucuna göre, dış hava sıcaklığının $31.4{ }^{\circ} \mathrm{C}$ olduğu koşullarda kararlı soğutma sağlandıktan sonra sera içindeki ortalama sıcaklığın $24.5{ }^{\circ} \mathrm{C}$ olduğu belirlenmiştir. Fan-Pad sistemi için hesaplanan saatlik ortalama soğutma etkisi ve soğutma etkinliği değerleri sırasıyla $6.96{ }^{\circ} \mathrm{C}$ ve \% 76.8 olarak saptanmıştır.

Anahtar Kelimeler: Soğutma etkinliği; Fan-Pad soğutma sistemi; Sera; Psikrometrik hesaplama; Sıcaklık ve bağıl nem

(C) Ankara Üniversitesi Ziraat Fakültesi

\section{Introduction}

Throughout the year, the demand for fresh vegetables and fruits has increased from day to day. In order to increase the amount of production of vegetables and fruits in dry areas, the greenhouse production period during the summer and autumn seasons can be expanded. However, the accumulated heat within the greenhouse due to the presence of high solar radiation causes to rising of the internal temperature (Tashoo et al 2014). Extreme temperatures inside the greenhouse will limit the plant growth, as well as its quality, eventually resulting in plant wilting and death. Even in greenhouses with proper and adequate circulation, the leaf temperature can be 5 $10{ }^{\circ} \mathrm{C}$ higher than the air temperature (von Zabeltitz 2011). Greenhouse crops must not be kept for long time at temperatures between 30 and $35^{\circ} \mathrm{C}$ (Bailey 2006). If level of air temperature in greenhouses where is used natural ventilation and shading system is higher than $28{ }^{\circ} \mathrm{C}$, it is recommended using of an artificial cooling system. Generally, evaporative cooling for greenhouses are made by using fogging, Fan-Pad cooling and misting methods (von Zabeltitz
2011). The system in which is suitable for hot and dry climate conditions among these is the Fan - Pad cooling system.

A Fan-Pad system consists of cellulose Pad panels, exhaust fans, water circulation pump and pipes. Pads and exhaust fans are located on opposing walls to cool plants growing in between Pad and Fan. Cellulose Pads have corrugated surfaces which are suitable for passing water and air. When inlet air passes through the wetted Pads, water evaporates using its sensible heat. In thermodynamics, this is known as an adiabatic process in which remains the constant of enthalpy without heat loss or gain (ASHRAE 2005).

Theoretical and experimental studies have been conducted by many researchers on Fan-Pad evaporative cooling systems. According to results of Kittas et al (2001) and Jain \& Tiwari (2002), the internal greenhouse temperatures were lower about 10 ${ }^{\circ} \mathrm{C}$ and $4-5{ }^{\circ} \mathrm{C}$ than outside temperature, respectively. Kittas et al (2003) presented and validated a model to predict the temperature and humidity gradient along the length of a large greenhouse equipped with 
Fan-Pad cooling system. Willist (2003) proposed a numerical model to predict air and crop temperatures when cooling system is used, not used. Fuchs et al (2006) developed a numerical model based on energy balance equation for evaporative cooling. Sabeh et al (2006) studied on amount of water needed for the cooling system to be used in a semi-arid region. Sethi \& Sharma (2007) reviewed the available cooling technologies such as ventilation, shading, evaporative cooling (Fan-Pad, misting, fogging, and roof cooling) and composite systems (earth-toair heat exchanger system and aquifer coupled heat exchanger system). Kumar et al (2009) reviewed on cooling technologies, design parameters, and their effects on the microclimate. Malli et al (2011) tested experimentally the thermal performances for three different cellulose Pad thicknesses, such as 75, 100 and $150 \mathrm{~mm}$. Lopez et al (2012) analyzed the characteristics of airflow and temperature distribution both Fan-Pad system and a low pressure fogging using sonic anemometry in an empty greenhouses.

In this paper, an experimental study was conducted to determine gradients of temperature and humidity formed along a greenhouse cooled when Fan-Pad system is used in Ankara conditions. The performance parameters of cooling system were calculated by using the method of psychrometric calculation according to external and internal data related with greenhouse environment.

\section{Material and Methods}

\subsection{Greenhouse experiments}

The experiments were conducted in a tomato greenhouse from April to August of 2009 at typical summer days with dry, sunny and cloudless. The crop was grown in a Venlo style research greenhouse located at University of Ankara, Turkey (39 57' 39' $\mathrm{N}, 32^{\circ} 51^{\prime} 49^{\prime \prime} \mathrm{E}$, and $855 \mathrm{~m}$ altitude).

The floor area of the greenhouse is $64 \mathrm{~m}^{2}(8 \mathrm{~m}$ x $8 \mathrm{~m}$ ). The orientation of greenhouse is east-west direction with an angle of $26.6^{\circ}$ from North. The greenhouse with galvanized steel frame is covered with polycarbonate sheets at thickness of $4 \mathrm{~mm}$ with double-walled and UV protection. The gutter and ridge heights of greenhouse having the roof slope of $26.5^{\circ}$ are $3 \mathrm{~m}$ and $4 \mathrm{~m}$, respectively. General dimensions and position of the greenhouse are shown in Figure 1. The greenhouse has six roof vents southfacing and two vents north-facing, and is equipped with Fan-Pad cooling system, as well as drip irrigation system. During the experiments, the tomato crop was grown in a soil medium. The greenhouse climate system consists of natural ventilation, shading, FanPads cooling, high-pressure fogging, drip irrigation, infrared heaters, and computer controller. During experiments, natural ventilation, shading, irrigation and Fan-Pad systems were actively used to ensure proper climate for growing crop.

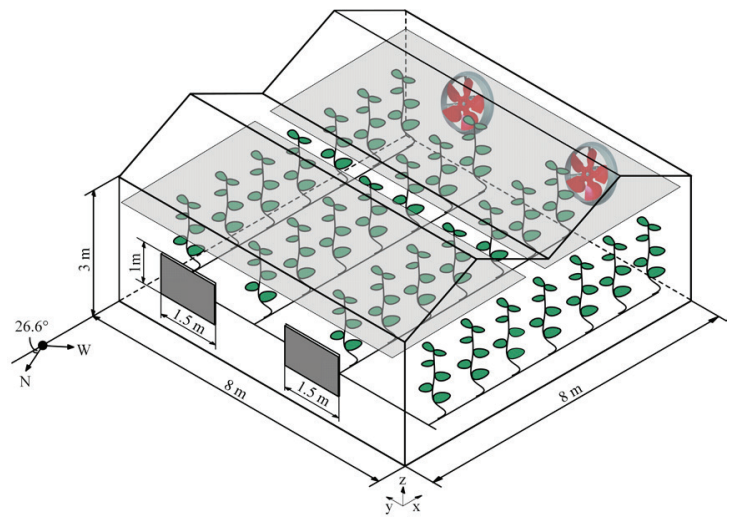

Figure 1- Schematic of experiment greenhouse used for cooling experiments

Şekil 1- Soğutma deneylerinde kullanılan seranın şematik gösterimi

Tomato (Lycopersicon esculentum L.) seedlings were transplanted into the greenhouse on April 01, 2009. The crop was configured in seven rows with 14 plants in each row, total 98 plants, as illustrated in Figure 2. Row spacing and plant spacing were 0.9 $\mathrm{m}$ and $0.4 \mathrm{~m}$, respectively.

Water need of plants is provided with drip irrigation system which has dripper discharge rate of $2 \mathrm{~L} \mathrm{~h}^{-1}$. A cable-drum drive system is used to extend and retract from truss to truss for shading of crop in greenhouse. The shading nets with solar transmittance of $50 \%$ in two-pieces at height of 2.5 $\mathrm{m}$ above ground are available in the greenhouse. 
However, the small sun flecks are occurrence on crop in the greenhouse by reason of the space of $1 \mathrm{~m}$ between these nets (Figure 2).

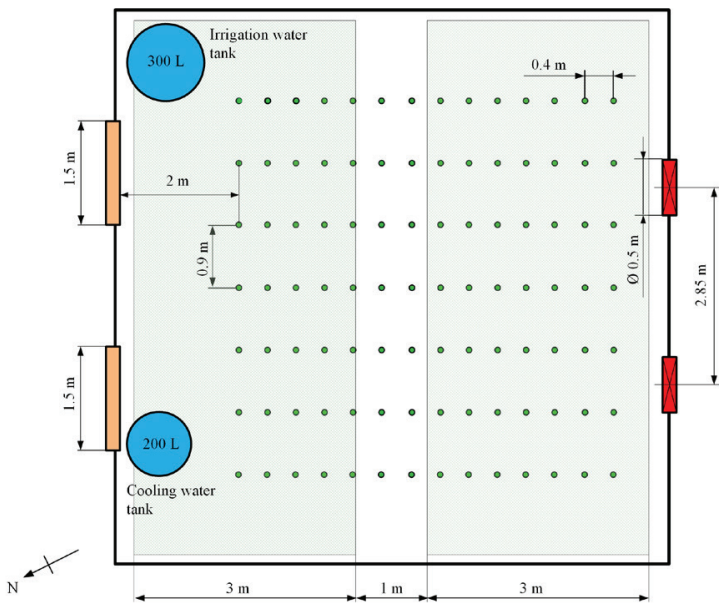

Figure 2- Configuration of crop, drip irrigation system Fan-Pad cooling system, and shading nets in experiment greenhouse

Şekil 2-Deney serasinda bitki, damla sulama, Fan-Pad soğutma sistemi ve gölgeleme perdesinin yerleşimi

\subsection{Fan-Pad cooling system}

Evaporative cooling Pads that are at thickness of $100 \mathrm{~mm}$ are placed in two frames, width of $1.5 \mathrm{~m}$ and height of $1 \mathrm{~m}$. They mount on the bonded gas concrete wall that is at height of $0.75 \mathrm{~m}$ above ground at north side. The distance between the pads and the first canopy line in rows was approximately $2 \mathrm{~m}$. Two exhaust fans are mounted to opposite side of the greenhouse as shown in Figure 2. The rotation axis of fans, which have the diameter of $0.5 \mathrm{~m}$, is at a height of $1.6 \mathrm{~m}$ above ground. The spacing between rotation axes of fans on side wall is $2.85 \mathrm{~m}$. Air flow capacity of each fan with $0.37 \mathrm{~kW}$ electrical motor power is 7 $\mathrm{m}^{3} \mathrm{~h}^{-1}$ at zero static pressure. Airflow directions from Pad to Fan are parallel to the crop rows.

A submersible water pump in water tank of 200 L has flow rate of $6 \mathrm{~m}^{3} \mathrm{~h}^{-1}$ at head of $3 \mathrm{~m}$. The water lost by evaporation from water tank is compensated from the tap water via floating valve. The water flow amount passing through the Pads is controlled by return valve.

\subsection{Measurements}

Measurements related with greenhouse environment were carried out by using seven sensors at different positions, as well as portable instruments. For this purpose, the five digital temperature and humidity sensors (SHT75, accuracy: $\pm 0.3{ }^{\circ} \mathrm{C}$ for temperature and $\pm 1.8 \%$ for humidity, Sensirion, Zurich, Switzerland) and two pyranometers (CM6, accuracy: $\pm 5 \mathrm{Wm}^{-2}$, Kipp and Zonen, The Netherlands) were used. Among them, two were located outside greenhouse for external measurements. The rest one pyranometer above the crop canopy, four temperature and humidity sensors were mounted within the crop canopy along the greenhouse.

Furthermore, a portable thermo-hygrometer (AZ8721, accuracy: $\pm 0.5^{\circ} \mathrm{C}$ for temperature and $\pm 2 \%$ for humidity, AZ Instrument, Shangai, China) and a portable hot wire anemometer (Lutron AM4204, accuracy: $\pm 0.8{ }^{\circ} \mathrm{C}$ for temperature and $\pm 1 \%$ for air velocity, Taipei, Taiwan) were used for instrumentation at different locations for greenhouse experiments.

SHT75 is a digital sensor with high accuracy, which is fully calibrated at the factory. SHT75 sensors were used together with programmable PIC16F628 microcontroller-based data acquisition modules (Microchip, AZ, USA). Each module was connected to a desktop computer over single serial bus line based on RS-232 settings (2400 baud rate, 8 data bits, no parity, and 1 stop bit) for serial data transmission. Temperature and humidity data were measured for every one minute, and were recorded in text files. Readings coming from two pyranometers were logged for every 30 minutes. Data logged were monitored by using a GUI program written in Borland Delphi 7. Wind speed data were taken from records of meteorological station in campus.

The sensor positions are illustrated in Figure 3 with numbers given from (1) to (7). (1): outside temperature and humidity sensor, (2-3-4-5): inside temperature and humidity sensors, (6): inside pyranometer, and (7): outside pyranometer. The sensors with numbers of (1-6-7) were mounted on a metal stand at $2.2 \mathrm{~m}$ of height from the ground outside greenhouse. The sensors with numbers of (23-4-5) were placed at intervals of $2.2 \mathrm{~m}$ at heights of 
$1.25 \mathrm{~m}$ above ground within the crop canopy along the greenhouse. These four sensors were named as "very close to pad", "next to pad", "middle", and "next to fan", respectively.

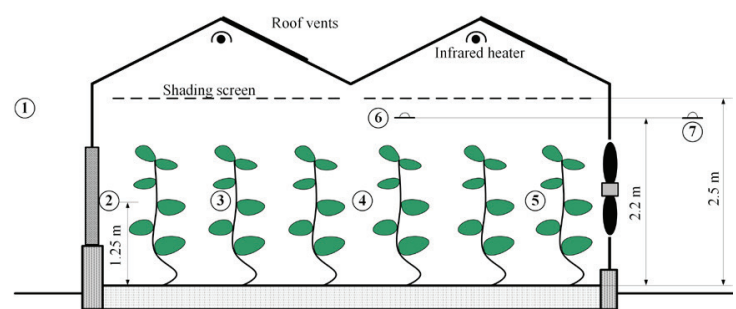

Figure 3- Positions of sensors placed inside and outside greenhouse, $1 \ldots 5$, temperature and humidity sensors; 6-7, pyranometers

Şekil 3-Sera içine ve dışına yerleştirilen sensörlerin konumlarl, 1... 5, sicaklık ve bağll nem sensörleri; 6-7, güneş ışınım sensörleri

\subsection{Performance parameters}

The difference between the outside temperature and inside temperature can be used as an important parameter to describe the cooling performance of Fan-Pad system. For this purpose, as an easy criterion, the cooling effect of Fan-Pad system is calculated from

$$
\Delta t_{c e}=t_{O}-t_{i}
$$

Where; $\mathrm{t}_{\mathrm{o}}$, outside air temperature $\left({ }^{\circ} \mathrm{C}\right)$; $\mathrm{t}_{\mathrm{i}}$, inside air temperature $\left({ }^{\circ} \mathrm{C}\right)$.

The cooling efficiency ( $\eta$ ) is determined as the ratio between the drop in air temperature after passing through the Pad and the maximum drop under conditions of air saturation.

$\eta=\frac{t_{d b^{(1)}-t_{d b^{(2)}}}}{t_{d b^{(1)}-t_{w b^{(1)}}}} \times 100$

Where; $\eta$, cooling efficiency $(\%) ; t_{d b}(1)$, the outside dry-bulb temperature of entering air to $\operatorname{Pad}\left({ }^{\circ} \mathrm{C}\right) ; \mathrm{t}_{\mathrm{db}}(2)$, the dry-bulb temperature of leaving air form $\operatorname{Pad}\left({ }^{\circ} \mathrm{C}\right)$; $t_{w b}(1)$, the outside wet-bulb temperature of entering air to Pad. However, two psychrometric properties of entering air to the system must be known:

1. Dry bulb temperature and the wet-bulb temperature, or
2. Dry bulb temperature and relative humidity

If both dry bulb temperature $\left(\mathrm{t}_{\mathrm{db}}\right)$ and the wetbulb temperature $\left(\mathrm{t}_{\mathrm{wb}}\right)$ is measured directly, the cooling efficiency can be calculated by substituting into equation (2). If dry-bulb temperature $\left(\mathrm{t}_{\mathrm{db}}\right)$ of air and relative humidity (rh) are known, its wet-bulb temperature $\left(t_{w b}\right)$ can be calculated by using psychrometric equations. The method of psychrometric calculations due to sensors used at measurements was employed to determine the cooling efficiency of evaporative Fan-Pad system.

\subsection{Method of psychrometric calculations}

The following psychrometric equations given by ASHRAE (2005) were used in all calculations. Relative humidity is defined as the ratio of the water vapor pressure to the saturation water vapor pressure at all temperature and pressures:

$r h=\frac{P_{w}}{P_{w s}}$

The humidity ratio (W, also known as moisture content or mixing ratio) of a given moist air sample is defined with following equation as functions of partial pressure of water vapor and total pressure $(\mathrm{Pa})$ :

$W=0.62198 \frac{P_{w}}{P-P_{w}}$

The total barometric pressure of moist air can be calculated according to altitude (Z):

$P=101.325\left(1-2.25577 \times 10^{-5} Z\right)^{5.2559}$

The humidity ratio at saturation $\left(\mathrm{W}_{\mathrm{s}}\right)$ can be calculated by substituting $\mathrm{P}_{w s}$ instead of $\mathrm{P}_{w}$ in equation (4).

The saturation vapor pressure over liquid water for temperature range of $0-200^{\circ} \mathrm{C}$ is given by following equation:

$\ln \left(P_{w s}\right)=\frac{C_{1}}{T}+C_{2}+C_{3} T+C_{4} T^{2}+C_{5} T^{3}+C_{6} \ln (T)$

Where;

$\mathrm{C}_{1}=-5800.2206$,

$\mathrm{C}_{2}=1.3914993$, 


$$
\begin{aligned}
& \mathrm{C}_{3}=-4.8640239 \times 10^{-2}, \\
& \mathrm{C}_{4}=4.1764768 \times 10^{-5}, \\
& \mathrm{C}_{5}=-1.4452093 \times 10^{-8}, \\
& \mathrm{C}_{6}=6.5459673 .
\end{aligned}
$$

In (6) equation, saturation pressure $P_{w s}$ is calculated in $\mathrm{Pa}$, using $\mathrm{T}$ the absolute temperature $\left(\mathrm{K}={ }^{\circ} \mathrm{C}+273.15\right)$.

\subsection{Adiabatic saturation process}

Evaporative cooling is an adiabatic process at constant enthalpy that is no heat loss and heat gain. It utilizes the exchange of energy between air and water. The energy needed to evaporate water is taken from the air, thus reducing air temperature. The energy in the air can be divided into two parts: sensible heat and latent heat. Sensible heat is a quantitative measure of the air temperature. Latent heat is the energy needed to evaporate the water in the air.

The enthalpy balance as follows to calculate the humidity ratio of moist air for the adiabatic condition must be defined (ASHRAE 2005):

$$
h+\left(W_{s}^{w b}-W\right) h_{w}^{w b}=h_{s}^{w b}
$$

Where; h, moist air specific enthalpy in kJ per kg dry air; $W_{s}^{w b}$ humidity ratio at saturation point at wet bulb temperature; $\mathrm{W}$, humidity ratio of moist air; $h_{w}^{w b}$, specific enthalpy in $\mathrm{kJ}$ per $\mathrm{kg}$ water of water added at wet bulb temperature; $h_{s}^{w b}$, specific enthalpy of moist air at wet bulb temperature in saturation.

In equation (3), substituting $\mathrm{h}, h_{w}^{w b}$, and $h_{s}^{w b}$ is solved for humidity ratio:

$$
W=\frac{\left(2501-2.326 t_{w b}\right) W_{s}^{w b}-1.006\left(t_{d b}-t_{w b}\right)}{2501+1.86 t_{d b}-4.186 t_{w b}}
$$

\subsection{Computation procedure}

In order to calculate the cooling efficiency of system according to equation (2), the wet-bulb temperatures need to be known. The wet-bulb temperatures were calculated with a convergence of $\mathrm{W}_{4}-\mathrm{W}_{8} \cong \pm$ 0.0005 from (3) to (8) equations using an iterative procedure written in Matlab 2007b (Mathworks, Natick, MA, USA).

\section{Results and Discussion}

The experiments were conducted under greenhouse conditions in Ankara at 26 - 30 August of 2009 when the crop was at full maturity. The external and internal climate data including solar radiation, temperature, humidity, and air speed were measured. During operating Fan-Pad cooling system, which was operated for approximately 2-4 hours daily, the internal shading nets were used to provide the more efficient cooling.

\subsection{External conditions}

Figure 4 indicates data that characterize the external climate during the experiment periods. As seen in Figure 4, the external air temperature, the relative humidity, the solar radiation, the wind speed ranged between $30-33{ }^{\circ} \mathrm{C}, 20-25 \%, 600-860 \mathrm{~W} \mathrm{~m}^{-2}$ and $2.1-3.8 \mathrm{~m} \mathrm{~s}^{-1}$ during high solar radiation hours (12:00-15:00), respectively.

\subsection{Internal conditions}

Internal solar radiation was approximately proportional to the external solar radiation. However, the internal solar radiation decreased, for example by $43.5 \%$ at noon, because of greenhouse frame, top radiant heater, cover and shading nets (Figure 5). During test trials, the solar radiation measured above plants ranged between 200 and 370 $\mathrm{W} \mathrm{m} \mathrm{m}^{-2}$. Figures 6 and 7 show the daily variations of temperature and humidity data measured at 2 , $3,4,5$ sensors positions along greenhouse. The temperature and humidity profiles were determined along horizontal axis between Fan and Pad at a daily time scale. Numbers in figures show the sensor positions: (1) external, (2) very close to Pad, (3) $2.2 \mathrm{~m}$ away from Pad, (4) middle (4.4 m away from $\mathrm{Pad}$ ), and (5) next to Fan (6.6 m away from Pad). Figures present how to change levels of temperature and humidity along greenhouse.

Cooling system was run up from 13:14 to 17:00, which were hours to be effective of cooling (Figures 6 and 7). It must be emphasized that the performance of Fan-Pad cooling system was analyzed for the time interval of 180 minutes. Hence, the two time stages were selected, one of which was 12:00 - 13:00 time 


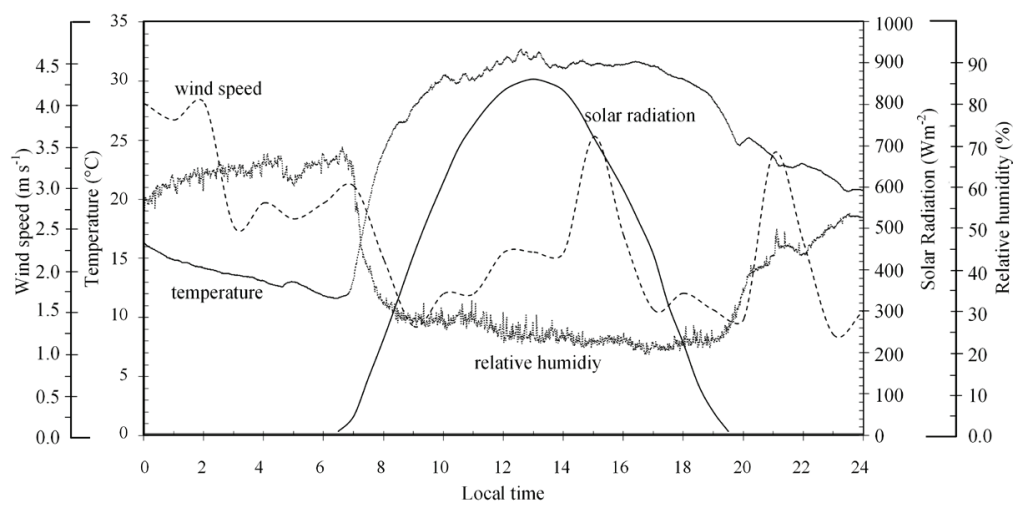

Figure 4- Daily variations of solar radiation, temperature, humidity, wind speed data measured outside greenhouse (26 August 2009)

Şekil 4-Sera dışında ölçülen güneş ışınımı, sıcaklık, bağıl nem ve rüzgâr hızı verilerinin günlük değişimleri (26 Ağustos 2009)

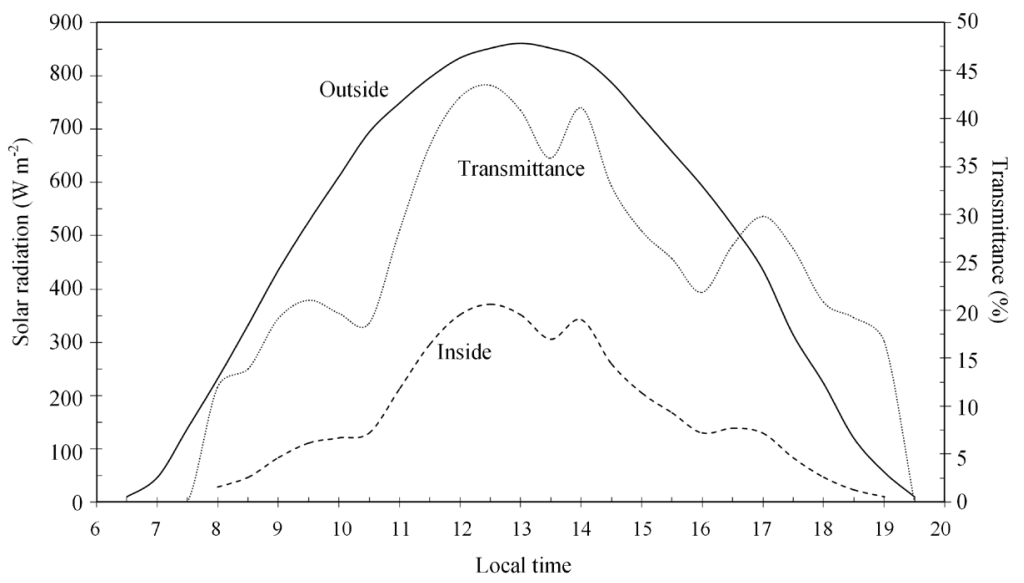

Figure 5- Daily variations of internal and external solar radiation (26 August 2009)

Şekil 5- Sera dışı ve içi toplam güneş ışınımının günlük değiş̧imi (26 Ağustos 2009)

stages which turned off the cooling system. The other of which was 14:00 - 15:00 time stage which turned on the system. At these time stages, the levels of hourly mean solar radiation prevailing above plants were approximately $350 \mathrm{Wm}^{-2}$ (cooling off), and $270 \mathrm{Wm}^{-2}$ (cooling on), respectively.

The variations of temperature and humidity along greenhouse were evaluated for two time stages. When turning off system between 12:00 and 13:00, the levels of hourly mean temperature calculated for 2, 3, 4 and 5 sensors positions were approximately
$33{ }^{\circ} \mathrm{C}, 31{ }^{\circ} \mathrm{C}, 32{ }^{\circ} \mathrm{C}$, and $30^{\circ} \mathrm{C}$, respectively, along the horizontal axis from Pad to Fan, After turning on Fan-Pad system, when being stable cooling conditions between 14:00 and 15:00, levels of hourly mean temperature for 2, 3, 4 and 5 sensors positions dropped to approximately $20^{\circ} \mathrm{C}, 24^{\circ} \mathrm{C}, 27{ }^{\circ} \mathrm{C}$, and $26^{\circ} \mathrm{C}$, and air at these points were colder as much as $12.75^{\circ} \mathrm{C}, 6.6^{\circ} \mathrm{C}, 4.9^{\circ} \mathrm{C}$ and $3.8^{\circ} \mathrm{C}$, respectively.

When turning off Fan-Pad system, the levels of hourly mean humidity calculated for 2, 3, 4 and 5 sensors positions were approximately $30 \%, 41 \%$, 
$39 \%$, and $47 \%$, respectively. It must be emphasized that the relative humidity levels inside greenhouse were more because of crop transpiration, even turning off the system. At 14:00 - 15:00, levels of hourly mean humidity calculated for 2, 3, 4 and 5 sensors positions rose up to approximately $68 \%, 56 \%, 50 \%$, and $57 \%$, respectively. The air at measurement positions along greenhouse was

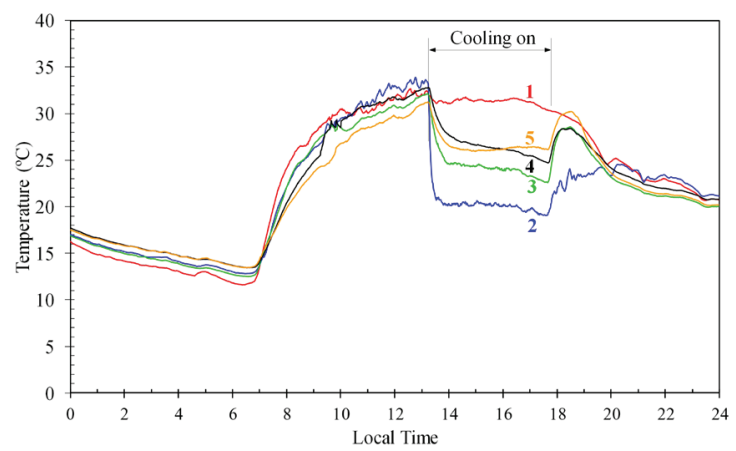

Figure 6- Daily variations of temperatures measured at different locations outside and inside a greenhouse cooled with Fan-Pad system (26 August 2009); Sensor positions: 1 , outside; 2 , pad; 3 , next to pad; 4, middle; 5 , next to fan

Şekil 6-Fan-Pad sistemi ile soğutulan bir seranın içinde ve dişında farklı konumlarda ölçülen sicaklıkların günlük değişimi (26 Ağustos 2009); Sensör konumlart: 1, diş; 2, pad; 3, pade yakın; 4, orta; 5, fana yakın more humid as much as $38 \%, 15 \%, 11 \%$ and $10 \%$, respectively. These results are integrated in Table 1 for both temperature and humidity gradients.

Our results are consistent with findings of past studies by Kittas et al (2001, 2003); Bartzanas \& Kittas (2005); Al-Helal et al (2006); Teitel et al (2010); Lopez et al (2012) related to the temperature and humidity distributions. For example, in a study performed by

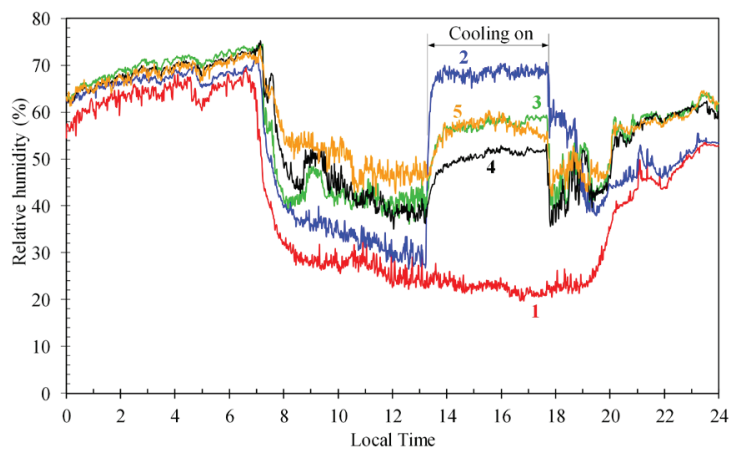

Figure 7- Daily variations of relative humidity measured at different locations outside and inside greenhouse of a greenhouse cooled with Fan-Pad system (26 August 2009); Sensor positions: 1, outside; 2, pad; 3, next to pad; 4, middle; 5 , next to fan

Şekil 7- Fan- Pad sistemi ile soğutulan bir seranın içinde ve dışında farklı konumlarda ölçülen bă̆ıl nemin günlük değişimi (26 Ağustos 2009); Sensör konumlarl: 1, dış; 2, pad; 3, pade yakın; 4, orta; 5, fana yakın

Table 1- Gradients of temperature and humidity according to sensor positions during periods turning off $(12: 00-13: 00)$ and on $(14: 00-15: 00)$ of cooling system

Çizelge 1- Soğutma sisteminin kapalı (12:00 - 13:00) ve açık (14:00 - 15:00) olduğu periyotlarda sensör konumlarına göre sıcaklık ve bă̆ll nem değişimleri

\begin{tabular}{ccccccc}
\hline & & \multicolumn{5}{c}{ Sensor positions } \\
\cline { 3 - 7 } & & Outside & Pad & Next to pad & Middle & Next to fan \\
& & 1 & 2 & 3 & 4 & 5 \\
\hline Temperature & Off & $32.05(0.29)$ & $33.02(0.41)$ & $31.10(0.45)$ & $31.93(0.39)$ & $30.02(0.52)$ \\
(S.D.) & On & $31.44(0.175)$ & $20.27(0.13)$ & $24.50(0.13)$ & $27.04(0.30)$ & $26.18(0.16)$ \\
${ }^{\circ} \mathrm{C}$ & $\Delta \mathrm{t}$ & - & 12.75 & 6.60 & 4.89 & 3.84 \\
\hline Humidity & Off & $24.69(1.51)$ & $29.52(1.48)$ & $41.06(1.77)$ & $38.55(1.09)$ & $46.79(1.59)$ \\
(S.D.) & On & $23.09(1.09)$ & $67.96(0.89)$ & $56.50(0.49)$ & $49.67(0.66)$ & $56.98(0.94)$ \\
$\%$ & $\Delta \mathrm{rh}$ & - & 38.44 & 15.44 & 11.12 & 10.19 \\
\hline
\end{tabular}


Bartzanas \& Kittas (2005), the difference between the air temperature entering to greenhouse and outside air temperature was about $10{ }^{\circ} \mathrm{C}$. In a research study carried out in a greenhouse equipped with Fan-Pad system by Lopez et al (2012), the inside air temperature was cooler up to $11.6^{\circ} \mathrm{C}$ than that of a natural ventilated greenhouse. However, it is emphasized that the main drawback of the Fan-Pad system was the horizontal temperature gradients to be with a maximum difference of $11.4{ }^{\circ} \mathrm{C}$ between the pads and fans. So far, however, there has been little discussion about horizontal humidity gradients between Pad and Fan.

Figure 8 shows the gradients of temperature and humidity along horizontal profile of greenhouse. Plotting drawn in Figure 8 indicates increasing approximately linearly of temperature between Pad and Fan. It can be said that the humidity variations along greenhouse remain approximately stable between Pad and Fan because of the crop transpiration. Giving details, the temperature increased up to $x=4 \mathrm{~m}$, then decreased. The humidity decreased up to $x=3 \mathrm{~m}$, and then remained stable. In other words, it was emphasized that the temperature at $\mathrm{x}=4.4 \mathrm{~m}$ was slightly higher while the relative humidity was lower due to small sun flecks arising from gap between two shading curtains. Kittas et al (2001; 2003) also reported the similar results on rose plants, which showed to be significantly differences on temperature and humidity at experiments with and without shading nets. If a general evaluation is made to define temperature and humidity profiles at $\mathrm{x}$-direction, the second - degree polynomial trend lines and equations can be derived with $\mathrm{R}^{2}=0.9946$ and $\mathrm{R}^{2}=0.974$, respectively (Figure 8 ).

Figure 9 shows the detailed performance parameters including cooling effect $\left(\Delta t_{c e}\right)$ and cooling efficiency $(\eta)$, as well as temperatures $\left(\mathrm{t}_{\mathrm{o}}, \mathrm{t}_{\mathrm{wb}} \mathrm{t}_{2}\right.$, and $\left.\mathrm{t}_{\mathrm{i}}\right)$ which correspond to external temperature, wet-bulb temperature, temperature in front of pad, and internal temperature, respectively. Here, $t_{i}$ represents the average of inside air temperatures that are measured at the four points inside greenhouse. Experiments results consist of cooling off (12:00 - 13:00) and cooling on $(14: 00-15: 00)$ time stages. As indicated in Figure 9, initially, before starting Fan-Pad system, the inside air temperature was higher or close to the outside air temperature. After starting system, the inside air temperature dropped until reaching to equilibrium. However, this reduction did not happen immediately, there was always a transition stage. The period when the cooling system is on includes "transition stage" and "stable cooling stage" (Figure 9). There are very significant differences between two time stages in terms of temperature variations and performance values.

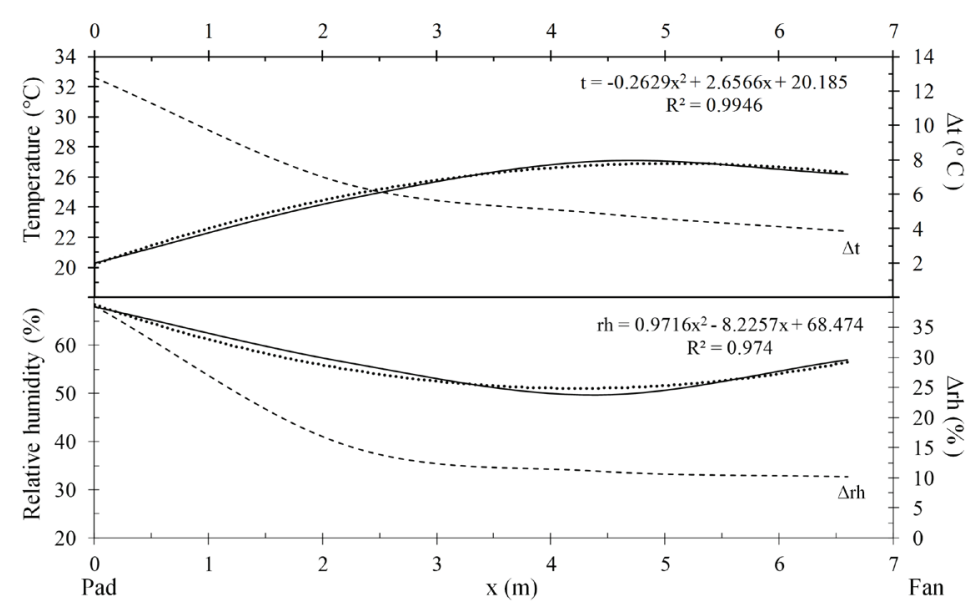

Figure 8- Gradients of temperature and humidity along greenhouse

Şekil 8-Sera boyunca oluşan sıcaklık ve bă̆ll nem değişimleri 


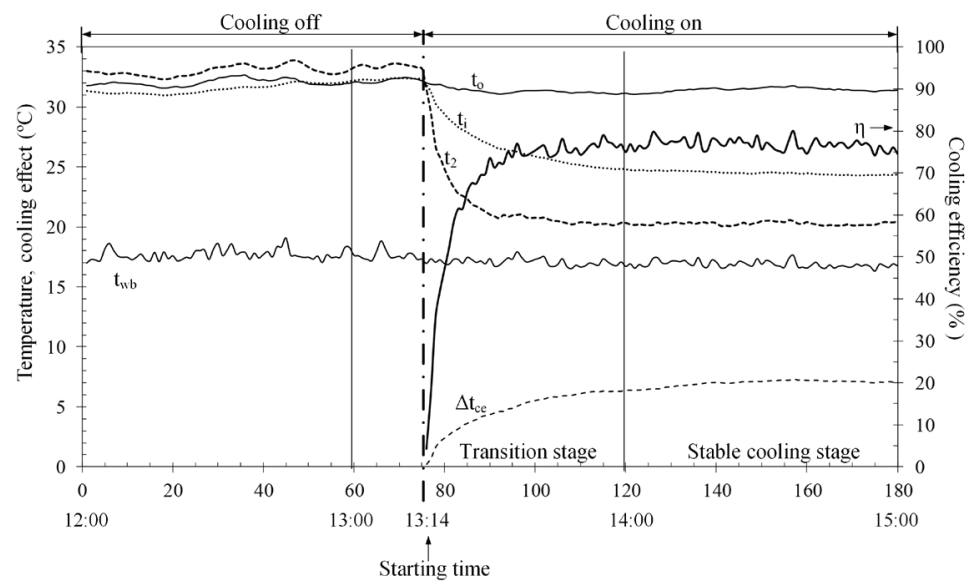

Figure 9- Performance parameters of Fan-Pad cooling system: cooling effect, cooling efficiency and temperature levels

Şekil 9- Fan-Pad soğutma sisteminin performans parametreleri: soğutma etkisi, soğutma etkinliği ve sicaklık seviyeleri

The results obtained related with the performance of greenhouse cooling system during experiments are summarized in Table 2. According to the calculation results, the internal temperature was $24.5{ }^{\circ} \mathrm{C}$ while external temperature was $31.44{ }^{\circ} \mathrm{C}$. It was observed that the internal temperatures were lower than external temperatures when turning on Fan-Pad system. This is an indication that sensible heat is converted to latent heat by water evaporation (Li \& Willits 2008). Values of the cooling effect and cooling efficiency of Fan-Pad system were found to be $\Delta \mathrm{t}_{\mathrm{ce}}=6.96{ }^{\circ} \mathrm{C}$ and $\eta=76.8 \%$, respectively. The maximum cooling efficiency was $80 \%$ at stable cooling stage. Bartzanas \& Kittas (2005) also found that the cooling efficiency of the pad-fan system was approximately $80 \%$.

The mean air temperature entering to greenhouse with air velocity of $0.8 \mathrm{~m} \mathrm{~s}^{-1}$ through the wet pad was $20.3^{\circ} \mathrm{C}$. It was observed that the cooled air temperature levels passing the wet pad with air velocity of 0.8-0.9 $\mathrm{m} \mathrm{s}^{-1}$ were approximately $12-13{ }^{\circ} \mathrm{C}$ lower than the outside air temperature. The maximum air velocity measured in front of Pads inside of the greenhouse was $0.9 \mathrm{~m} \mathrm{~s}^{-1}$, but as moving away from Pads, it was observed that the air velocities reduced up to $0.2-0.3$ $\mathrm{m} \mathrm{s}^{-1}$ in crop rows, which were also consistent with results obtained by Li \& Willits (2008); Lopez et al (2012). ASABE (2008) has recommended the mean

Table 2- Performance quantities of Fan-Pad cooling system: mean, minimum and maximum values Çizelge 2- Fan-Pad soğutma sisteminin performans büyüklükleri: ortalama, minimum ve maksimum değerler

\begin{tabular}{lcccc}
\hline Quantities & Symbol & Mean (S.D.) & Minimum & Maximum \\
\hline Outside temperature $\left({ }^{\circ} \mathrm{C}\right)$ & $t_{o}$ & $31.4(0.17)$ & 31.1 & 31.8 \\
Wet-bulb temperature $\left({ }^{\circ} \mathrm{C}\right)$ & $t_{w b}$ & $16.9(0.27)$ & 16.3 & 17.6 \\
Temperature in front of pad & $t_{2}$ & $20.3(0.13)$ & 20.1 & 20.6 \\
Inside temperature $\left({ }^{\circ} \mathrm{C}\right)$ & $t_{i}$ & $24.5(0.14)$ & 24.3 & 24.7 \\
Cooling effect $\left({ }^{\circ} \mathrm{C}\right)$ & $\Delta t_{c e}=t_{o}-t_{i}$ & $6.96(0.26)$ & 6.4 & 7.3 \\
Cooling efficiency $(\%)$ & $\eta$ & $76.8(1.31)$ & 74.1 & 80.0 \\
\hline
\end{tabular}


air velocity of $1.27 \mathrm{~m} \mathrm{~s}^{-1}$ entering to the greenhouse through the pad. However, if applying the high air velocities on Pads, increasing electricity costs and decreasing cooling efficiency. According to our experiment results, it can be emphasized that the air velocities of $0.8-0.9 \mathrm{~m} \mathrm{~s}^{-1}$ are appropriate to provide the efficient cooling.

The efficiency of Fan-Pad system is an indicator of air saturation efficiency. The closer temperature measured in front of pad inside greenhouse is to wetbulb temperature, higher cooling efficiency of pad. However, it is emphasized that the highest efficiency values can be produced at low air velocities (Franco et al 2014). As the air velocity decreases, the length of time that the air comes into contact with the water increases, also increasing the saturation of the air, consequently the saturation efficiency is higher (Franco et al 2010).

According to experiment results of Franco et al 2014 , it was provided that the maximum values of Fan-Pad cooling system efficiency were between $71 \%$ and $69 \%$ at low air velocities close to $0.5 \mathrm{~m} \mathrm{~s}^{-1}$. According to our experimental findings, the cooling system efficiencies ranged between $74 \%$ and $80 \%$ at air velocities of $0.2-0.3 \mathrm{~m} \mathrm{~s}^{-1}$ measured in crop rows. Willits (2003) suggested the higher air-flow rates than $0.05 \mathrm{~m}^{3} \mathrm{~m}^{-2} \mathrm{~s}^{-1}$ for Fan-Pad system to provide efficient cooling. Air flow rate of fans used in our system is $0.06 \mathrm{~m}^{3} \mathrm{~m}^{-2} \mathrm{~s}^{-1}$ at zero static pressure. These air flow rates are suitable for adequate cooling.

Although the length of the greenhouse is not long, the significant temperature and humidity gradients were observed, which become the coolest air near the pads and the warmest air near exhaust fans of the inside air temperature. The levels of these gradients are affected by many factors, such as greenhouse geometry, positions of shading nets, external climate conditions, air flow rate, crop density and temperature of circulating water. The efficiency of cooling system was quite high due to the dry and warm outside climate conditions. Increasing the air flow passing the pad does not improve the air saturation efficiency. Circulation fans can be used to provide the uniform temperature distribution between pads and exhaust fans.

\section{Conclusions}

This study evaluated the cooling performance of a greenhouse cooled with Fan-Pad under hot and dry climate conditions like in Ankara. During experiments, natural ventilation, shading, irrigation and Fan-Pad systems were actively used to ensure proper climate for growing crop. In order to define greenhouse experiment conditions, the external and internal data including solar radiation, wind speed, temperaturehumidity and internal air velocity were measured.

The temperature and humidity profiles were determined along horizontal axis between Fan and Pad. The evaluations were made for the different sensor positions: external, very close to Pad, next to Pad, middle, and next to Fan. It was observed that there were the significant temperature and humidity gradients along the greenhouse from Pad to Fan, even being a small greenhouse where the experiments were made about Fan-Pad cooling. The levels of these gradients are affected by many factors, such as greenhouse geometry, positions of shading nets, external climate conditions, fan air flow rate, crop density and temperature of circulating water. According to the horizontal temperature and humidity profiles, the second - degree polynomial trend lines and equations were derived.

The performance evaluations were made by using two quantity, such as the cooling effect and cooling efficiency. In order to determine the cooling efficiency of Fan-Pad system, the method of psychrometric calculations was used. The wet-bulb temperatures were calculated by using an iterative procedure. The results obtained showed that the cooling efficiency was low at starting time. For this purpose, two stages, a transition stage and stable cooling stage, were defined. The cooling efficiency increased until reaching to the equilibrium between sensible heat and latent heat for adiabatic cooling process. The hourly mean cooling effect and cooling efficiency performance parameters, as well as the average of air temperatures inside greenhouse, were calculated.

Cooling efficiency is a function of pad temperature, outside temperature and its wet-bulb temperature. The closer pad temperature measured in front of pad inside greenhouse is to wet-bulb temperature, higher cooling efficiency of pad. In 
order to provide the more effective cooling, there is no need to increase the air flow rate; however, if water temperature circulating in the system and the external air humidity can be reduced, the cooling efficiency can be increased. Furthermore, the circulation fans in the greenhouse can be used for the uniform temperature and humidity distribution.

\begin{tabular}{|ll|}
\hline Abbreviations and Symbols \\
\hline$S . D$. & standard deviation \\
$R^{2}$ & determination of coefficient \\
$h$ & moist air specific enthalpy $\left(\mathrm{kJ} \mathrm{kg}^{-1}\right)$ \\
$P$ & total barometric pressure $(\mathrm{Pa})$ \\
$P_{w}$ & water vapor pressure $(\mathrm{Pa})$ \\
$P_{w s}$ & saturation water vapor pressure $(\mathrm{Pa})$ \\
$t^{2}$ & air temperature $\left({ }^{\circ} \mathrm{C}\right)$ \\
$t_{o}$ & outside air temperature $\left({ }^{\circ} \mathrm{C}\right)$ \\
$t_{i}$ & inside air temperature $\left({ }^{\circ} \mathrm{C}\right)$ \\
$t_{d b}$ & dry-bulb temperature $\left({ }^{\circ} \mathrm{C}\right)$ \\
$t_{w b}$ & the wet-bulb temperature $\left({ }^{\circ} \mathrm{C}\right)$ \\
$\Delta t$ & temperature difference $\left({ }^{\circ} \mathrm{C}\right)$ \\
$\Delta t$ & the cooling effect $\left({ }^{\circ} \mathrm{C}\right)$ \\
$T$ & absolute temperature $(\mathrm{K})$ \\
$W$ & humidity ratio $\left(\mathrm{g}\right.$ kg dry air $\left.{ }^{-1}\right)$ \\
$W$ & Saturation humidity ratio $(\mathrm{g} \mathrm{kg} \mathrm{dry} \mathrm{air-1)}$ \\
$Z$ & altitude (m) \\
$\eta$ & cooling efficiency $(\%)$ \\
$w$ & water vapor \\
$w S$ & saturation water vapor \\
$x$ & horizontal axis \\
\hline
\end{tabular}

\section{References}

Al-Helal I, Al-Abbadi, N M \& Al-Ibrahim A (2006). A study of evaporative cooling pad performance for a photovoltaic powered greenhouse. Acta Horticulture 710:153-164

ASABE (2008). Heating, ventilating and cooling greenhouses. ASABE standards. ANSI /ASAE EP406.4 JAN2003 (R2008). St. Joseph, American Society of Agricultural and Biological Engineers

ASHRAE (2005). Psychrometrics, Ch 6: 6.1-6.17, In: American Society for Heating, Refrigeration, and Air Conditioning Engineers Fundamentals. SI ed. Atlanta

Bailey B (2006). Natural and Mechanical Greenhouse Climate Control. Acta Horticulture 710: 43-54

Bartzanas Th \& Kittas C (2005). Heat and Mass Transfer in a Large Evaporative Cooled Greenhouse Equipped with a Progressive Shading. Acta Horticulture 691: 625-631

Franco A, Valera D L, Madueno A, Pena A (2010). Influence of water and air flow on the performance of cellulose evaporative cooling pads used in Mediterranean greenhouses. Transactions of the $A S A B E$ 53(2): 565-576
Franco A, Valera D L, Pena A (2014). Energy Efficiency in Greenhouse Evaporative Cooling Techniques: Cooling Boxes versus Cellulose Pads. Energies 7: 1427-1447

Fuchs M, Dayan E \& Presnov E (2006). Evaporative cooling of a ventilated greenhouse rose crop. Agriculture and Forest Meteorology 138: 203-215

Jain, D \& Tiwari G N (2002). Modeling and optimal design of evaporative cooling system in controlled environment greenhouse. Energy Conversion and Management 43(1): 2235-2250

Kittas C, Bartzanas T \& Jaffarin A (2001). Greenhouse evaporative cooling: measurement and data analysis. Transactions of the ASAE 44(3): 683-689

Kittas C, Bartzanas T, \& Jaffarin A (2003). Temperature Gradients in a Partially Shaded Large Greenhouse equipped with Evaporative Cooling Pads. Biosystems Engineering 85(1): 87-94

Kumar K S, Tiwari K N \& Madan K Jha (2009). Design and technology for greenhouse cooling in tropical and subtropical regions: A review. Energy and Buildings 41: $1269-1275$

Li S \& Willits D H (2008). An experimental evaluation of thermal stratification in a fan-ventilated greenhouse. Transactions of the ASABE 51(4): 1443-1448

Lopez A, Valera D L, Molina-Aiz F D \& Peña A (2012). Sonic anemometry to evaluate airflow characteristics and temperature distribution in empty Mediterranean greenhouses equipped with pad-fan and fog systems. Biosystems Engineering 113(4): 334-350

Malli A, Seyf H R, Layeghi M, Sharifian S \& Behravesh H (2011). Investigating the performance of cellulosic evaporative cooling pads. Energy Conversion and Management 52(7): 2598-2603

Sabeh N C, Giacomelli G A \& Kubota C (2006). Water Use for Pad and Fan Evaporative Cooling of a Greenhouse in a Semi-Arid Climate. Acta Horticulture 719: 409-416

Sethi V P \& Sharma S K (2007). Survey of cooling technologies for worldwide agricultural greenhouse applications. Solar Energy 81(12): 1447-1459

Tashoo K, Thepa S, Pairintra R, Namprakai P (2014). Reducing the Air Temperature Inside the Simple Structure Greenhouse Using Roof Angle Variation. Tarım Bilimleri Dergisi-Journal of Agricultural Sciences 20(2): 136-151

Teitel M, Atias M \& Barak M (2010). Gradients of temperature, humidity and $\mathrm{CO}_{2}$ along a fan-ventilated greenhouse. Biosystems Engineering 106(2): 166-174

Zabeltitz C (2011). Integrated Greenhouse Systems for Mild Climates Climate Conditions, Design, Construction, Maintenance, Climate Control. Springer, Hannover

Willits D H (2003). Cooling fan-ventilated greenhouses: a modelling study. Biosystems Engineering 84(3): 315-329 